\title{
A construção de um problema público: ativismo no centro histórico de Lisboa
}

\author{
The construction of a public problem: \\ activism in Lisbon's historic center
}

Heitor Vianna Moura [I]

\begin{abstract}
Resumo
Parte-se, neste artigo, do estudo empírico de coletivos, associações e instituições atuantes na cidade de Lisboa e da mobilização de referências teórico-metodológicas da sociologia pragmática. Busca-se analisar como uma série de denúncias de casos individuais de despejos ganhou o estatuto de coletividade, tornando a luta pelo direito à habitação no centro histórico da capital um assunto prioritário nas agendas públicas local e nacional. Partindo do entendimento de que os problemas públicos da cidade não são dados da realidade, e sim construções político-sociais, pretende-se contribuir com as reflexões sobre o ativismo urbano, mapeando suas estratégias de publicização e de sensibilização de públicos.
\end{abstract}

Palavras-chave: ativismo urbano; Lisboa; direito à habitação; problema público; sociologia pragmática.

\begin{abstract}
This article presents an empirical study of collectives, associations, and institutions that are active in the city of Lisbon and mobilizes theoretical and methodological references of pragmatic sociology. The aim is to analyze how a set of individual complaints of evictions gained collective status, making the struggle for the right to housing in the capital's historic center a priority on the local and national public agendas. Based on the understanding that the city's public problems are not an objective reality, but social and political constructions, this research aims to contribute to reflections on urban activism, mapping its dissemination strategies and public awareness campaigns.
\end{abstract}

Keywords: urban activism; Lisbon; right to housing; public problem; pragmatic sociology. 


\section{Do engajamento pessoal ao problema público}

Foi, através de uma carta recebida no final de 2017, que o inquilino de um apartamento localizado na rua de São José, centro de Lisboa, conheceu as novas condições do seu contrato de aluguel (ou arrendamento, para usar a terminologia local), até então submetido a um regime de renovação anual automática. A proposta formulada pela senhoria, proprietária e administradora de todo o edifício, reservava a ele duas possibilidades: a saída forçada em menos de dois meses ou o pagamento de um valor $25 \%$ superior ao acordado dois anos antes, em 2015. Para assegurar a sua prerrogativa sobre o destino da propriedade, ela recorreu ao Novo Regime do Arrendamento Urbano ${ }^{1}$ de 2012, que facilita o processo de rescisão de contrato. Com isso, estaria aberta a possibilidade de negociação de um novo acordo entre os interessados, incluindo a proposta de aumento muito acima do coeficiente nacional de atualização de rendas (calculado, no ano de 2017, em $1,0054 \%)$.

Impossibilitado de suportar o novo valor, o inquilino produziu uma réplica. Lançando uma carga de suspeita sobre a legalidade da ação da proprietária, ele questionou o desrespeito ao prazo contratual e o não registro da carta com aviso de recepção, como determina a legislação. Tal estratégia, assentada no mesmo repertório jurídico por ela mobilizado, permitiu o reestabelecimento do acordo nos termos anteriores, para o alívio do locatário. Foi, por meio dessa situação problemática, que o autor deste artigo teve o seu primeiro contato com o problema da habitação nas zonas centro e centro histórico ${ }^{2}$ de Lisboa. 0 imóvel em disputa foi o local em que ele viveu durante sua experiência de estágio doutoral, e o inquilino ameaçado de despejo, o seu namorado. Enquanto problema pessoal, o seu período de resolução não se estendeu por mais de um mês, mas foi suficiente para gerar uma inquietação íntima que acabou por produzir um interesse investigativo.

Em uma cidade em que grande parte dos habitantes vive em imóveis alugados realidade que contrasta com o restante do país, em que a habitação própria predomina (Guerra, 2011) -, estima-se que situações do tipo aconteçam diariamente. Sobretudo em contextos em que o mercado imobiliário e de habitação se encontra aquecido, como sugerem os estudos mais recentes e abrangentes sobre a questão do Instituto Nacional de Estatística de Portugal (2011, 2013). Lisboa enfrentou um aumento global de $54 \%$ nos contratos de aluguel entre 2016 e 2018 (Confidencial Imobiliário, 2018). Valores que são ainda mais expressivos no centro histórico, onde os imóveis voltados à moradia temporária, ao alojamento turístico (ou "alojamento local", como é referido pela legislação nativa) ${ }^{3}$ e ao investimento estrangeiro se multiplicam em detrimento dos destinados ao aluguel de longa duração. Processo que, por um lado, expressa a capacidade da cidade de atrair investimentos nacionais e internacionais para o seu parque imobiliário, contribuindo com a dinamização da economia local. Por outro lado, pela própria natureza especulativa e predatória desse tipo de atividade, dificulta que a população mais vulnerável acesse o mercado de habitação nessas áreas, empurrando-a para as regiões mais periféricas, onde a provisão de serviços públicos é escassa e o mercado de trabalho pouco vigoroso. 
A legislação em vigor, por sua vez, é frequentemente apontada por moradores, ativistas e acadêmicos como um dos fatores responsáveis pelo crescimento do número de despejos na capital, sendo alvo de grande contestação social. Questionamento que começa a ter eco nas esferas de representação política, sobretudo após o ano de 2015, quando o governo central (coligação de centro-direita), ${ }^{4}$ responsável por aprovar uma série de medidas austeritárias no pós-crise capitalista de 2012, foi substituído por uma coalização de partidos de esquerda e centro-esquerda, o Partido Comunista Português, o Bloco de Esquerda, os Verdes e o Partido Socialista, cujo secretário-geral, António Costa, foi escolhido primeiro-ministro. No âmbito das políticas urbanas, a mudança ofereceu condições políticas para o questionamento das medidas aprovadas pelo governo anterior, encontrando na Câmara Municipal de Lisboa, presidida desde 2007 pelo Partido Socialista, um ambiente favorável de enfrentamento. Atuação, no entanto, nem sempre vista com otimismo por aqueles que são afetados pela questão.

Do mesmo jeito que não existem problemas de pesquisa desvinculados da trajetória e das práticas dos que se dedicam a investigá-los, os problemas públicos também não emergem como dados da realidade. São construções políticas e sociais que dependem, em primeiro lugar, da capacidade de os agentes diretamente afetados produzirem denúncias que deem um estatuto coletivo aos seus problemas, transformando uma série de casos dispersos e individuais (como a experiência pessoal do autor, com que se iniciou este artigo), em parte integrante de uma causa comum. Em seguida, supõem que os grupos formados em torno dessas causas acessem a arena pública e definam os assuntos por eles considerados problemáticos como prioritários e, com isso, sejam capazes de exigir medidas que contribuam com a sua resolução, o que se faz por meio de estratégias de publicização e sensibilização de públicos que ultrapassam os que são diretamente afetados pelo problema (Spector e Kitsuse, 2001; Gusfield, 1981; Cefaï, 2009).

Essas são as linhas gerais do caso que resultou no fenômeno que o presente artigo busca analisar: a transformação do problema da habitação no centro histórico de Lisboa em um problema público de expressão local e nacional. Interessa conhecer os meios que permitiram que coletivos, associações e instituições formadas em torno de assuntos específicos ultrapassassem a retórica do interesse individual (self-interest) por meio da construção de uma gramática de justificação pública, que exige dispositivos públicos de resolução do problema. ${ }^{5} \mathrm{O}$ desafio investigativo desdobra-se em muitas outras questões: "Que grupos conseguiram acessar a arena púbica?"; "Que dispositivos dramáticos e teatrais foram mobilizados?"; "Que regimes de engajamento e princípios de justiça são evocados para interpelar a opinião pública e os poderes públicos?".

Fruto de uma experiência de imersão etnográfica pelo centro histórico de Lisboa, da observação participante em eventos e reuniões de coletivos de luta pela habitação e de conversas informais com acadêmicos, militantes e moradores, o presente artigo busca contribuir com o debate sobre a atuação e a eficácia de coletivos urbanos na luta pelo direito à habitação. Ou, de forma mais ampla, produzir uma reflexão que colabore com a construção de meios de resistência e de insurgência contra os processos de financeirização e de pilhagem 
de bens e serviços sociais, como o solo urbano e a habitação. 0 que se buscou fazer a partir do reconhecimento de estratégias e repertórios que, ao mesmo tempo que visam a combater problemas locais, conectam-se com redes mais amplas de ativismo urbano global.

Ademais, intenta-se promover uma reflexão teórica sobre a construção de problemas públicos assentada em três pressupostos caros às referências teórico-metodológicas mobilizadas ao longo da análise. Ao focar o olhar sobre a qualidade dramática e performativa da construção de problemas públicos, pretende-se, com Gusfield (1981 e 2012), recusar a ideia de que o que mobiliza o público é a objetividade e a veracidade dos fatos representados por dados técnicos ou análises científicas, sem negar que a sua constituição tem um compromisso com a realidade. ${ }^{6}$ Além disso, busca-se dar mais atenção ao que Cefaï e colaboradores definem como arena pública, ${ }^{7}$ permitindo colocar em contato os diferentes princípios lógicos que integram a constelação de cenas que se sobrepõem (Cefaï, 2002, 2009, 2017; Cefaï, Mota e Veiga, 2011). Por fim, seguindo a tradição da sociologia pragmática (em especial a sociologia da crítica de Boltanski), procura-se levar a sério as operações críticas dos atores ordinários e sua capacidade de operar diferentes sensos de justiça, rompendo com as perspectivas que entendem todas as relações sociais como relações de forças (nomeadamente as de inspiração marxista ou bourdieusiana) e com as que interpretam as ações dos atores como estratégias de otimização dos seus interesses, própria de uma sociologia inspirada na tradição utilitarista (Boltanski, 2000, 2014, 2016; Boltanski; Thévenot, 2006).

0 artigo está dividido em quatro momentos. No primeiro, será feito um breve percurso pelas políticas urbanas portuguesas, em especial as voltadas para enfrentamento do problema da habitação. Notas que só fazem sentido quando relacionadas com a lógica mais ampla de acumulação pós-fordista, as crises econômicas que solaparam a economia nacional nas últimas décadas e as intervenções internacionais que acompanharam os planos de recuperação econômica. Em seguida, será analisada a construção de uma arena interorganizacional como estratégia de acesso da arena pública. Opção que tem como objetivo abandonar a ideia abstrata de "problemas da sociedade" em favor de uma análise de coletivos, associações e instituição que se engajam na definição do problema e na cobrança pela sua resolução (Spector; Kitsuse, 2001). Em um terceiro momento, será investigado o processo de produção de uma gramática de justificação pública por parte desses grupos, assumindo as páginas do jornal Público como mediação reveladora dos dispositivos retóricos de engajamento por eles mobilizados em diferentes cenas públicas. As linhas finais serão dedicadas a discutir as potencialidades e os limites das ações e das estratégias dos grupos analisados adiante da crescente mercantilização do espaço urbano.

\section{A crise do Estado Providência, o Plano Troika e a mercantilização da moradia}

O longevo regime do Estado Novo, inaugurado por Salazar em 1933 e derrubado em 1974, deixou marcas profundas no quadro de precariedade habitacional português. As cidades portuguesas receberam um grande contingente 
populacional vindo do campo e, posteriormente, das antigas colônias na segunda metade do século XX. Fenômeno impulsionado pelos processos de industrialização, urbanização e descolonização. Devido à incapacidade do Estado de responder às novas demandas por habitação, proliferou-se o desenvolvimento informal e clandestino por novas moradias. 0 governo optou por medidas simbólicas em sua abrangência, como a oferta insipiente de habitações econômicas por meio do Fundo de Fomento de Habitação (1969) e o congelamento das rendas (Silva, 1994). No quadro político-social, tais ações se associavam a "vertente paternalista" do regime, que via nas políticas um meio de neutralizar certos setores da sociedade por meio da promoção da integração social e, sobretudo, familiar (Serra, 1997).

Foi apenas com a queda do Estado Novo e com a agitação social, política e econômica que se seguiu ao projeto de construção de um Estado de Bem-Estar Social que se encontraram condições favoráveis para a implementação de políticas orientadas pelos valores de universalidade e de igualdade de acesso aos bens sociais (Barata, 2014). 0 que se fez sentir com o reconhecimento da habitação como direito constitucional em 1976 e a inauguração de políticas habitacionais descentralizadas e com um forte componente de participação comunitária, por vezes sustentada pelo processo de autoconstrução (Amilcar et al., 2011). Viu-se, pela primeira vez, uma intervenção mais direta e sistemática do Estado na promoção da moradia, ainda que o volume de investimento público do setor fosse significativamente inferior aos demais componentes da despesa social - como educação, saúde e segurança social (Santos; Telles; Serra, 2004).
Com a redução na arrecadação fiscal e a proliferação do ideário neoliberal, caracterizado pela desconfiança em relação ao papel do Estado e por uma aposta na centralidade do mercado e da competitividade, as políticas de habitação portuguesas sofreram uma nova revisão; cenário que se manifesta também em outros países europeus (Rolnik, 2015). ${ }^{8}$ De provedor de habitação de custo acessível, o Estado passou a atuar como facilitador da atuação do mercado privado por meio da concessão de crédito bancário subvencionado para a construção e a aquisição da casa própria. Como consequência dessa política, produziu-se um enorme endividamento das famílias portuguesas, alimentou-se a lógica especulativa e rentista do setor imobiliário, estrangulou-se o setor de aluguel e incentivou-se o processo de suburbanização e de exclusão socioespacial (Guerra, 2011; Fonseca e Malheiros, 2011; Carmo, Ferrão e Malheiros, 2014). Com o abandono da ideia de moradia como um bem social e a aposta na transferência da responsabilidade aos indivíduos pelo seu próprio bem-estar, o país hoje tem um dos estoques públicos de habitação social mais baixos da Europa. ${ }^{9}$

Lógica que, após a crise do capitalismo financeiro de 2008, assumiu uma feição ainda mais radical (Mendes, 2014). Como condição para o empréstimo de 8 bilhões de euros ao Estado Português, foi imposto, pelo Fundo Monetário Internacional, pela Comissão Europeia e pelo Banco Central Europeu (a dita Troika), a aprovação do que ficou conhecido como Plano Troika (2011), composto por medidas que esvaziaram os fundos públicos destinados à habitação social, favoreceram abertura do mercado nacional e, por fim, dinamizaram o mercado privado de aluguel. Para atrair o investidor 
estrangeiro, o regime fiscal favorável aos Residentes Não Habituais (2009) ${ }^{10}$ passou a se articular com o programa Golden Visa (2012). ${ }^{11}$ O Novo Regime de Arrendamento Urbano (2012), por sua vez, foi responsável pela extinção de contratos celebrados antes da década de 1990 e pela atualização dos aluguéis para valores incompatíveis com a renda dos antigos inquilinos. Quadro que criou um contexto fiscal e legal com rebatimentos profundos no mercado imobiliário da cidade de Lisboa - centro político e econômico do país.

Durante a segunda metade do século XX, Lisboa já havia experimentado uma significativa mudança em suas dinâmicas urbano-territoriais que alterou a lógica de determinação do valor da terra interurbana. Por meio de investimentos públicos e privados nas regiões mais periféricas, a cidade viu a sua mancha urbana expandir-se (Nunes, 2010; Salgueiro, 2001); o que foi seguido pela desvalorização do parque imobiliário situado em seu centro e centro histórico, resultado da fuga das classes mais altas, do desinvestimento do setor público e do abandono e da degradação dos imóveis existentes. Desvalorização que permitiu a permanência de uma classe média empobrecida e, em alguns casos, a chegada e a fixação de grupos étnicos com status social menos reconhecido (Fonseca e Malheiros, 2011).

Uma vez consolidada a sua área metropolitana, esboçou-se uma tendência de recentralização da cidade no final do século $X X$, à semelhança de outras capitais mundiais (Harvey, 2012; Bidou-Zachariassen, 2006). 0 processo foi induzido pelo poder público através de programas de promoção e de estímulo à reabilitação de edifícios degradados. Com esse fim, foram criados o Programa de Recuperação de Imóveis Degradados (1976) e o Programa de Reabilitação Urbana (1985), em que a preocupação com a manutenção da população residente podia ser notada. 0 que se altera com a constituição das Sociedades de Reabilitação Urbana (2014), em uma altura em que o mercado passa a ser o princípio orientador das medidas nesse setor. Foi o suficiente para criar condições favoráveis à atração de investidores privados, que elegeram o centro histórico como nova fronteira de extração da mais-valia fundiária (Mendes, 2013 e 2014). Afinal, a combinação de sua localização central com o estado de degradação e abandono de parte dos imóveis criava uma oportunidade de investimento seguro de reprodução do capital imobiliário via rent gap, processo observado em outras cidades do globo (Smith, 2012).

Por fim, há ainda que considerar outro fator, quando se analisam as dinâmicas do mercado imobiliário e suas consequências nas dinâmicas habitacionais da região: o turismo urbano. Com a crise do capitalismo de 2008, o setor tornou-se central na criação de empregos e na mitigação do impacto das políticas de austeridade nas famílias portuguesas e, ainda, alimentou uma rede de agentes econômicos que viram no turismo a possibilidade de ampliar seus lucros. Foi o caso dos proprietários de imóveis no centro histórico, que passaram a investir em alojamentos e em negócios voltados para o turismo. 0 que acabou por retirar do mercado tradicional de aluguel um número significativo de imóveis, fortalecendo a já desigual relação entre procura e oferta desse tipo de bem. ${ }^{12}$

0 resultado foi imediatamente sentido por aqueles que, dependendo dos contratos de aluguel, viram suas moradias serem transformadas em um ativo financeiro e, com isso, passaram a ter a sua permanência ameaçada. 
Em pouco tempo, os casos de desalojamento direto e indireto, tanto de moradores como de comércios tradicionais, começaram a se avolumar, ganhando destaque na mídia local e nacional e passando a ecoar nas esferas de representação política. Enfim, forma-se a combinação que tece o pano de fundo do problema que será analisado nas próximas páginas: a exploração descontrolada das terras urbanas centrais por agentes econômicos nacionais e estrangeiros, depois de um longo período de desinteresse, com a revolta daqueles que passaram a encontrar na ação coletiva a única saída às ameaças de despejo.

\section{A construção de arenas interorganizacionais como estratégia de acesso à arena pública}

O movimento Morar em Lisboa marcou a sua estreia, na cena pública, com a publicação de uma carta aberta dirigida aos representantes políticos e aos citadinos denunciando a "drástica subida dos valores do arrendamento de habitação que tem levado à expulsão de população das áreas mais centrais da cidade" (Morar em Lisboa, 2017). Lançada no primeiro mês de 2017, a carta-manifesto apresentou pela primeira vez, ao público mais amplo, as razões que motivaram a criação do grupo, o problema que elegeram como prioritário e as propostas de enfrentamento.

Para fundamentar suas denúncias, o grupo apresentou dados que confirmariam o aquecimento desenfreado do mercado imobiliário voltado para a habitação ${ }^{13}$ e elegeu os "responsáveis causais" ${ }^{14}$ pelo problema: 1) o Estado, por meio da criação de instrumentos legais e financeiros para atrair investimento privado internacional no parque imobiliário português (Nova Lei do Arrendamento Urbano, Lei dos Residentes Não Habituais e Golden Visa Portugal); e 2) dinâmica subjacente do capitalismo financeiro global, com forte expressão no mercado imobiliário e turístico local. As consequências, segundo o grupo, seriam perceptíveis pela dificuldade de acesso ao mercado de habitação no centro histórico e o deslocamento forçado de seus antigos moradores para as regiões mais periféricas da cidade.

Apontado como "responsável político" pelo aprofundamento das desigualdades socioterritoriais locais, o Estado, na figura do governo central, dos deputados e da Câmara Municipal, é o principal alvo do movimento. Aos representantes políticos, o Morar em Lisboa exigiu uma nova política de habitação e de ordenamento territorial, medidas de regulação do setor do turismo e a revisão das políticas fiscais destinadas aos investidores e estrangeiros. Como estratégia de publicização, a divulgação da carta aberta foi capaz de garantir uma expressiva inserção nos meios de comunicação de massa locais e nacionais, ${ }^{15}$ angariar cerca de cinco mil signatários nos meses seguintes e assegurar a presença de seus porta-vozes em encontros, audiências públicas e fóruns, ${ }^{16}$ fortalecendo a pauta da habitação na Assembleia da República, na Câmara Municipal e nas Juntas de Freguesia. ${ }^{17}$

A força simbólica da iniciativa não pode ser explicada apenas pela qualidade dos argumentos desenvolvidos ou pelo agravamento do problema apontado, visto que documentos semelhantes já haviam sido produzidos por acadêmicos, ativistas e representantes políticos nos anos anteriores. A sua potência parece 
residir na capacidade de o Morar em Lisboa conectar uma pluralidade de coletivos, associações e instituições já existentes em torno de uma "situação problemática" comum, produzindo uma "arena interorganizacional" (Cefaï, Mota e Veiga, 2011). Trata-se de uma estratégia que faz uso dos laços de solidariedade e de pertencimento constituídos na trajetória de atuação de cada um desses grupos; grupos que, ao se encontrarem e conectarem, produzem um novo modo de engajamento e de participação na ação coletiva. A associação contribuiu para fortalecer a capacidade de questionamento, crítica e negociação dos envolvidos.

Entre os 37 signatários coletivos, estão grupos diversos, entre os quais: 1) os atuantes na luta pelos direitos de permanência de moradores; ${ }^{18} 2$ ) os preocupados com produção social da arquitetura; ${ }^{19} 3$ ) os defensores da preservação do patrimônio cultural e arquitetônico; ${ }^{20} 4$ ) os comprometidos com o ativismo artístico; ${ }^{21} 5$ ) os ligados ao ativismo urbano; ${ }^{22}$ 6) os atuantes na produção acadêmica do conhecimento; ${ }^{23}$ 7) os envolvidos na luta pelo direito dos trabalhadores e dos reformados; ${ }^{24}$ 8) os atuantes no campo da inovação social e da produção de desenvolvimento local; ${ }^{25}$ 9) os incentivadores da prática de esporte; ${ }^{26} 10$ ) os militantes no campo socioambiental; ${ }^{27} 11$ ) os defensores dos direitos das pessoas que vivem com HIV ou em risco de o contraírem; ${ }^{28}$ e 12) os que lutam pela transparência dos processos decisórios. ${ }^{29}$

Diante de tamanha pluralidade de agendas de ação envolvidas, interessa perceber como, a despeito dos assuntos entendidos como prioritários para cada um dos grupos, o tema do acesso à habitação no centro histórico da cidade conseguiu aglutiná-los em uma luta comum. Para isso, dois processos foram fundamentais para o sucesso da iniciativa: a produção de uma agenda de defesa da coisa pública ancorada em lógicas de proximidade e a construção da ideia de posse compartilhada do problema.

Ao investigar a construção de um problema público, percebem-se dois movimentos aparentemente contraditórios. Inicialmente, há um "emaranhado de estruturas de proximidade do mundo vivido" que são indissociáveis do processo de engajamento público (Cefaï, 2011, p. 70). As experiências vividas, as sociabilidades locais e os laços territoriais ajudam a construir um regime de pertencimento e de engajamento não público, que tece uma rede de apoio e solidariedade voltada para a própria comunidade. Simultaneamente, sob o risco de serem acusados de localismo e comunitarismo, os grupos precisam rejeitar a lógica de proximidade, valendo-se de uma gramática de justificação pública para universalizar suas denúncias e reivindicações. É por meio dessa lente interpretativa que se propõe, aqui, a leitura da carta produzida pelo Morar em Lisboa: encarando o documento como a materialização da passagem de ações ancoradas em lógicas de proximidade para a construção de uma agenda que se pretende desvinculada de amarras particularistas.

Destaca-se que os grupos signatários não operaram dispositivos próprios de universalização de suas questões, mas a construção de uma arena interorganizacional assentada em uma agenda unificada possibilitou um engajamento público mais amplo. No caso sob análise, a Associação Habita pelo Direito à Habitação e à Cidade e a Associação dos Inquilinos Lisbonenses passaram a focar sua atenção no centro e, em especial, no centro histórico, enquanto o Renovar a Mouraria, os Vizinhos 
do Areeiro, Pensionistas e Idosos dos Olivais e a Associação do Patrimônio e População de Alfama fortaleceram a luta em outras localidades e, por fim, o Left Hand Rotation e a Academia Cidadã entenderam a luta pela moradia local como uma pauta urbana prioritária. Todos eles, grupos e atores engajados numa ação coletiva comum, passaram a assumir uma nova identidade, temporária, fabricada pelo "tipo de problema diante dos quais se reúnem ou se confrontam, de acordo com as configurações provisórias de aliança e de inimizades nas quais se envolvem" (ibid., p. 73).

Outro processo relevante, quando se analisa a capacidade de sensibilização de públicos, é a disputa empreendida por grupos em torno de determinados problemas. Gusfield (1981) argumenta que a trajetória dos problemas é marcada por sua apropriação por parte de grupos diversos, que, em momentos e situações específicas, passam a ter controle e autoridade sobre $\mathrm{o}$ assunto. $\mathrm{O}$ que de imediato coloca uma questão fundamental: se os grupos não têm os mesmos poder, influência e autoridade na definição de um problema, o que permitiu que a rede estudada estabelecesse uma relação de domínio sobre ele? A resposta parece estar na transferência da posse fracionada do problema para um controle coletivo unificado, representado pela carta do Morar em Lisboa. Processo que não está livre de disputas internas e externas, visto que a relação de autoridade nunca é cristalizada, mas objeto de constante contestação.

Vê-se, portanto, que, para a compreensão do processo de construção de um problema público, é preciso recuperar os arranjos institucionais que disputam a autoridade sobre o assunto. E sobre o conjunto de dispositivos de ação e de enunciação, visto que, na perspectiva pragmática que fundamenta este texto, não se está diante de processos assentados unicamente na força e no poder daqueles que anunciam, mas na capacidade de produção de argumentos socialmente aceitos (Boltanski, 2014, 2016)..$^{30}$ Por isso é tão importante, para esses grupos, a construção de enunciados assentados em princípios de justiça universalizáveis, reconhecidos por públicos que compartilham entre si expectativas e valores. Essa dimensão simbólica será analisada nas próximas páginas.

\section{A construção de gramáticas de justificação pública como dispositivo de engajamento}

"Moro em Alfama e recebi uma carta recentemente para deixar a casa porque o senhorio não me renova o contrato. Estou desesperada. Tenho o meu marido acamado, não fala e não anda; o que é quer eu vou fazer nesta situação?" Com a voz embargada e os olhos úmidos, Elisa interrompe a sua fala e apoia o microfone sobre o colo. Gesto que é imediatamente respondido com uma salva de palmas e manifestações de apoio da plateia que lotava o salão principal do Palácio da Independência no dia 5 de abril de 2018. Antes dela, Carla denunciou o corte da água e da luz para forçar a sua saída; Eduardo lamentou a ordem de despejos que recebeu do proprietário da casa em que vive com a mulher há 60 anos; e Diana chorou ao lembrar a mudança de sua família para a periferia da cidade.

No palco, lisboetas compartilharam a dor e o medo de serem despejados da casa em que sempre moraram. Na plateia, moradores, 
ativistas e apoiadores acompanharam as falas emocionadas e manifestaram sua solidariedade com gritos de "Não; não sai!"; "Força!"; "Porcos; senhorios porcos!"; e "Não; vão nos tirar!". Reações registradas por duas câmeras de televisão e por jornalistas que cobriam o ato. Assim foi durante toda a primeira parte do evento promovido pela Junta de Freguesia de Santa Maria Maior, unidade político-administrativa integrada pelos bairros de Alfama, da Baixa, do Castelo e da Mouraria, que registrou nos últimos anos as maiores taxas de evasão de eleitores e a mais expressiva concentração de imóveis destinados ao alojamento turístico na cidade (Quaternaire Portugal, 2017). ${ }^{31}$

Intitulado "Rostos do Despejo - Pelo direito a habitar no centro histórico", o evento buscou fazer dos relatos individuais de sofrimento um mecanismo de sensibilização e de adesão de apoiadores. Tal intenção se revela já no título escolhido para o evento, que, com o acréscimo do termo "rostos", passa a personificar, pela ideia jurídica de "despejo", a dor daqueles que são obrigados a deixar seus lares, desafiando o senso de justiça dos que defendem a legalidade do ato. Estratégia que o seu porta-voz, o presidente Miguel Coelho, ${ }^{32}$ não escondeu do público:

Enquanto organizávamos o evento, pensamos em como passar a nossa mensagem; se deveríamos lidar com ele de uma maneira mais agressiva. Nós pensamos muito se deveríamos chocar. E chegamos à conclusão de que sim, era necessário chocar para sensibilizar a opinião pública e todos aqueles que têm responsabilidade nessa matéria [...] queríamos mostrar que essas pessoas existem. As pessoas que vieram hoje são apenas uma pequena amostra das pessoas de carne e osso que estão a passar por esse drama. Não estamos falando de estatística; estamos falando do sofrimento de pessoas reais.

As juntas de freguesias em questão, mesmo não sendo a instância competente para criar uma legislação que proteja o inquilinato ou a desenvolver políticas sociais expressivas para sua fixação, transformaram os casos aparentemente dispersos e particulares em um drama capaz de sensibilizar mesmo aqueles não diretamente afetados pelo fenômeno. ${ }^{33}$ É o que Spector e Kitsuse definiram como a primeira fase da "história natural dos problemas sociais": a "afirmação da existência de uma condição que ele [o grupo que denuncia] define como nociva ou danosa (harmful), ultrajante ou chocante (offensive)", provocando, no seu público, um sentimento de indignação e compaixão (Spector e Kitsuse, 2012, p. 90). Efeito que teve na audiência presente reação imediata, mas que pretendeu alcançar também aqueles que lá não estiveram e acompanharam a repercussão do evento pelos meios de comunicação.

Por um lado, a decisão de usar os depoimentos dos moradores como estratégia de sensibilização prova que a construção de um problema público não é apenas "cognitiva", mas "envolve afetividades, sensibilidade e moralidades coletivas" (Cefaï, Mota e Veiga, 2011, p. 42). Por outro, o segundo momento do evento demonstra que, para o problema aceder ao nível de generalidade, outras gramáticas são necessárias. A passagem da crítica (baseada em provas emocionais) para a denúncia (assentada em categorias de justiça universalizáveis) aconteceu quando o presidente da junta (Santa Maria Maior), mobilizando categorias técnicas, jurídicas e estatísticas, questionou o equilíbrio econômico da atividade turística, 
defendeu a preservação do patrimônio material e cultural local, denunciou a desigualdade socioespacial gerada pela nova dinâmica do mercado de habitação e ainda advogou pelo direito constitucional à habitação.

Da singularidade do sofrimento, passa-se à generalidade do fenômeno. Não por acaso, são mobilizadas estatísticas - antes acusadas de serem incapazes de expressar o sofrimento daquelas famílias. Com dados diversos (sobre a evasão de eleitores, o crescimento de licenças para imóveis para alojamento turístico, o aumento da procura pelo apoio jurídico da junta e o tratamento fiscal desigual dado aos contratos de aluguel de longa e de curta duração), o porta-voz construiu um sistema de provas e de argumentos que compõe a realidade pública do fenômeno. Lidos pela perspectiva da retórica, os dados produzidos por organizações técnicas e científicas não se opõem aos depoimentos pessoais que os antecederam. Ao contrário, confirmam a realidade do problema por eles denunciado e, por meio disso, geram adesões que superam os atingidos diretamente por ele, assumindo a condição de um problema público da cidade.

0 evento promovido pela Junta de Freguesia de Santa Maria Maior é apenas um exemplo de como os grupos fazem uso de estratégias retóricas e performativas para dar, ao tema da habitação no centro histórico, o estatuto de problema público. Agora é necessário analisar o argumentário por eles mobilizado. Ao focar a atenção nas operações críticas que os atores e grupos empreendem quando se engajam na crítica e na denúncia de situações por eles julgadas como problemáticas, volta-se para a perspectiva desenvolvida por Boltanski e Thévenot - ou, mais especificamente, para o "trabalho de modelização" ${ }^{34}$ empreendido pelos atores e grupos estudados (Boltanski e Thévenot, 2006; Boltasnki, 2000). Esforço que será seguido por uma tentativa de construir analiticamente o princípio de justiça em que cada um deles se apoia, a construção tipificada de vítima e a identificação dos responsáveis pelo problema.

O jornal Público foi escolhido como fonte privilegiada, devido ao fato de, entre os diários de grande circulação, ter dado maior atenção ao tema. Enquanto fonte documental, o jornal será analisado como mediação reveladora das diferentes cenas que constituem a arena pública e, com isso, das variáveis lógicas e regimes de engajamento que se cruzam. Essa opção metodológica só é possível quando se tem em conta que os meios de comunicação são tanto dispositivos fundamentais na publicização e na fundamentação dos argumentos e das ações dos grupos em questão quanto produtores de agendas próprias, as "agendas midiáticas" (Cefaï, 2002). As páginas dos jornais não são expressão da totalidade dos grupos que participam do debate ou do conjunto de argumentos mobilizados por eles, mas um meio possível para se apreender parte do argumentário mobilizado na arena pública.

Para começar, destacam-se argumentos cujo princípio encontra-se na base de um mundo orientado pelo regime de justiça, que é a recusa da legitimidade das ações e dos engajamentos apoiados na violência, isso é, quando existe um flagrante abandono da busca pela construção do bem comum. Nessas situações, as disputas não se dão em termos argumentativos ou racionais, mas se referem à negação da humanidade daqueles que se enfrentam (Boltanski, 2000, pp. 105-118). Para sustentar a defesa do que se chamará de princípio de legalidade, não faltam exemplos nos relatos: 
cortes de luz nas áreas comuns dos edifícios, encerramento do fornecimento de luz e gás nas habitações; produção excessiva de baruIho e de sujeira por obras; retirada de caixa de correio, de corrimãos, de janelas, de portas e de claraboias; e outras medidas executadas com o intuito de degradar as condições de habitabilidade daqueles que se recusam a sair dos prédios.

Também faz parte desse conjunto de ameaças o uso da força e de mecanismo de fraude e de trapaça na produção de documentos de encerramento dos contratos de aluguel. Nos jornais, diversas reportagens foram dedicadas ao tema. ${ }^{35}$ Em coletivos, associação e instituições, a preocupação deu origem a ações diversas, como a oferta de apoio jurídico, caso da Associação Habita e da Junta de Freguesia de Santa Maria Maior, ${ }^{36}$ e a produção de materiais voltados para a denúncia dos casos de violência. ${ }^{37} \mathrm{Na}$ Câmara Municipal, por meio da inciativa do Bloco de Esquerda, ${ }^{38}$ foi criada uma linha telefônica exclusivamente dedicada a prestar auxílios aos munícipes em situação de despejo ou de "bullying imobiliário", apelido que passou a ser empregado para nomear a prática de assédio por parte dos senhorios. ${ }^{39}$

$O$ segundo conjunto de argumentos analisados tem como base a defesa de tipos sociais entendidos como desamparados, aqui nomeado princípio de proteção dos vulneráveis. Por meio da ideia tipificada de vítima, os coletivos buscaram associar a condição de precariedade e desvantagem social a três grupos: idosos, pessoas com deficiência ou incapacidade e famílias monoparentais. Uma vez mais, o jornal serviu como ferramenta importante de denúncia, dessa vez publicizando casos dramáticos de membros dos três tipos anteriormente referidos. ${ }^{40} \mathrm{O}$ mesmo foi feito pelos coletivos de luta pela habitação, que procuraram dar destaque ao drama das vítimas: seleção cuidadosa dos depoimentos que compuseram o evento "Rostos do Despejo"; colagem de fotografias dos moradores mais idosos nas ruas da Mouraria; tentativa do coletivo Stop Despejo de evitar o despejo de Rita, mãe solteira com dois filhos; a organização do evento "Habitação para todos: direito do sênior a ficar", pela Associação de Inquilinos Lisbonenses. Na cena parlamentar, vê-se que as denúncias acabaram por produzir respostas públicas, como a aprovação da moratória provisória de todos os despejos que envolviam inquilinos com mais de 65 anos ou $60 \%$ de incapacidade que tenham um contrato de aluguel de 15 anos ou mais. ${ }^{41}$ Foi colocada em pauta a discussão de um programa governamental de apoio ao acesso à habitação por meio de empréstimos bonificados, em que as famílias monoparentais teriam entrada facilitada. ${ }^{42}$

Apesar de o discurso produzido pelos coletivos raramente fazer referência aos direitos presentes na Constituição Portuguesa, ${ }^{43}$ é interessante destacar que os dois primeiros grupos são diretamente referidos em seus artigos "art. 71 Cidadãos Portadores de Deficiência" e "art. 72 Terceira Idade" -, que garantem direitos e proteções sociais especiais (Assembleia da República, 2005). Já, quanto ao terceiro, a referência está no cruzamento do "art. 36 - Família", "art. 69 - Infância" e "art. 70 Juventude", que asseguram que as famílias devem receber a proteção do Estado quando se encontram impedidas de garantir o cuidado de seus membros mais jovens, caso de muitas famílias monoparentais. Tal ocorrência ajuda a explicar a alta capacidade de sensibilização e de engajamento de argumentos assentados nesse tipo de princípio, visto que a legislação, 
por princípio, é a cristalização dos valores universais e abstratos compartilhados pelo grupo cujas relações são por ela reguladas.

Outros dois princípios que integram o repertório são a igualdade e a justiça social. Eles se expressam, em grande medida, nas acusações de que alguns grupos estariam desfrutando de privilégios no acesso ao mercado de habitação, enquanto a população local estaria sendo expulsa das regiões centrais e históricas da cidade. Entre os privilegiados, estão os investidores e aposentados estrangeiros beneficiados por medidas de atração de investimentos externos via vantagens fiscais como os Vistos Gold e o Regime de Residentes não Habituais. ${ }^{44}$ Já os fundos de investimento imobiliário, os agentes econômicos do setor de turismo e o proprietário que destina seu imóvel para o aluguel de curta duração (alojamento turístico) são recriminados pelas ações que incentivam o setor do turismo - como os programas de reabilitação do patrimônio edificado, a aprovação simplificada de empreendimentos hoteleiros e a frágil regulação e tributação do alojamento turístico. ${ }^{45}$ Do lado oposto, estão todos aqueles que dependem do mercado de aluguel para viver, não conseguindo competir com os que entendem a terra e os imóveis como meios de captura de renda, de fonte de lucro. ${ }^{46}$

Com isso, procura-se confrontar mundos com lógicas de funcionamento opostas: o das relações de troca e o das relações de uso. ${ }^{47}$ No primeiro, prevalece a concepção da habitação como uma mercadoria, regulada pelas operações de compra, de venda e de aluguel; no segundo, predomina a ideia da habitação como um direito social, que deve ser preservada das relações de mercado. Por meio de cartazes e palavras de ordem, os grupos estudados ocuparam as ruas da cidade, no dia 22 de setembro de 2018, , para defender a primazia do segundo sobre o primeiro, como se viu nas demandas: 1) pelo respeito ao direito constitucional da habitação 48 ("Artigo 65, direito à habitação"; "Habitação é um direito social", "Ocupar não é um prazer, soluções é um dever, artigo 65", “Já, já, já, direito à habitação"); 2) pela condenação da transformação das moradias em ativo financeiro pelo setor bancário, imobiliário e turístico ("Não há orgulho em ser banqueiro", "Acabem com o [Visto] Gold", "Houses are not profits", "Renda = Roubo", "Chega de Avareza", "Os bancos sugam as nossas vidas", "Stop financialization", "Especulação imobiliária = habitação precária", "Bom remédio para a habitação é o capitalismo cair no chão", "Fim da especulação!", "Era uma vez Lisboa, o mercado não perdoa", "E se a sua vida fosse vendida para um fundo abutre?"); 3) pela denúncia da expulsão das famílias de seus locais de moradia, sobretudo nos bairros mais centrais ("Hands of our houses", "Pelas nossas vidas, pelas nossas casas, lutamos", "Vidas importam, lucro não", "A cidade unida, jamais será vendida", "O vosso paraíso é o nosso inferno", "Sai, sai, sai. Sai da minha rua. E leva a sua grua").

Faz parte do mesmo repertório a defesa do princípio de mistura social, que se valida por oposição a dois outros princípios lógicos: o da segregação e o da elitização dos espaços; profundamente rejeitados pelos grupos estudados. Entre os apontados como "responsáveis causais" pela homogeneização social dos bairros históricos e centrais, estão aqueles que, por meio da proliferação da atividade turística e da abertura internacional do mercado imobiliário, estariam provocando a saída de seus antigos moradores: os turistas e os estrangeiros. 
Tal atribuição de responsabilidade é observável no material produzido para manifestação anteriormente mencionada, que tem os dois tipos como alvos preferencias de ataques, seja exigindo a sua saída ou o controle de sua presença: "Chega de alojamento local"; "Tendas para turistas, não moradores"; "Turistas não votam"; "Think befores use Airbnb"; "Turismo massivo é terrorismo"; "Alojamento local não é habitação, mas esgotou a oferta"; "This is $A L$ [alojamento local] for you. E eu?"; "Lisboa = Disneylândia"; "A cidade é nossa, tchau endinheirados". Seja, ainda, denunciando os efeitos de sua chegada: "Se a cidade os habitantes tiram, como ficamos?"; "Nós queremos viver na cidade, com certeza"; "Take back the cities"; "A Baixa é nossa, Alfama é nossa, o Castelo é nosso. Levem suas câmeras para outro lugar". Denúncia que também tem espaço na comunicação social, que dá grande destaque à tomada dos bairros centrais por esses grupos, ${ }^{49}$ ou em iniciativas que acusam a privatização e a turistificação da cidade, expandindo a questão para seus espaços públicos. ${ }^{50}$

Ao acessarem a arena pública, os atores não inventam do zero as justificações dirigidas ao público; "buscam[-nas] em repertórios de argumentação, típicos e recorrentes, identificáveis em outras situações" (Cefaï, 2011, pp. 90-91). Não por acaso, o pressuposto de que a cidade e seus espaços têm um valor coletivo, não mercantilizável, é facilmente identificável em outras situações de luta urbana. Em relação aos três últimos princípios referidos, vale destacar que o discurso técnico e acadêmico, sobretudo aquele produzido no campo do urbanismo, da geografia e das ciências sociais, também teve um papel relevante na produção de argumentos dos grupos estudados. É exemplar, nesse sentido, a circulação de termos cunhados em ambientes regulados por acordos e convenções acadêmicas em outras cenas, ganhando novos sentidos e conotações. Foi o caso da noção de "gentrificação", 51 que passou a aparecer com frequência nos textos da imprensa diária, ${ }^{52}$ assim como integrar o repertório militante, como se viu em intervenções nos muros da cidade e nos cartazes produzidos: "Gentrificação, não"; "Fuck gentrification"; "Good bye, Mouraria. Hello, gentrification"; "Gentrifuckme".

Essa circulação de repertórios foi impulsionada também pelos atores que integram o mundo acadêmico, que, por vias diversas, passaram a intervir mais diretamente no debate público sobre a cidade. Na cena midiática, por exemplo, observou-se a presença recorrente de acadêmicos nas páginas dos jornais, seja por meio entrevistas concedidas, seja por artigos por eles assinados..$^{53}$ Nota-se também sua forte presença na cena militante, produzindo e assinando manifestos públicos ${ }^{54}$ e participando diretamente de coletivos. ${ }^{55} \mathrm{O}$ mesmo se observa na cena parlamentar, em que os dados e diagnósticos produzidos por suas pesquisas ajudam a dar realidade ao problema e, eventualmente, servem de base na construção de medidas voltadas para resolvê$-10 .{ }^{56} \mathrm{~A}$ capacidade de influir na disputa só é possível na medida em que esses atores ajustam seus discursos e repertório aos ambientes nos quais intervêm, embora mantendo seu estatuto de pesquisador e, por isso, legítimos enunciadores de um discurso socialmente aceito como desinteressado e objetivo. 0 que não significa que a sua autoridade não possa ser alvo de contestação e, eventualmente, ter sua competência desacreditada (Gusfield, 1981, pp. 74-76). Não por acaso, umas das estratégias empregadas para desqualificar $e$ 
desautorizar o discurso acadêmico é acusação de filiação de seus enunciadores com causas políticas e sociais, comprometendo a suposta objetividade do conhecimento por ele produzido ou, nas palavras do entrevistado Luís Mendes, o seu "habitus acadêmico" (Moura, 2018).

O sexto princípio está relacionado com a ideia de tradição, mais especificamente com a preservação das práticas sociais e culturais dos bairros estudados. Após uma série de medidas públicas voltadas para a recuperação do patrimônio físico do centro histórico da cidade, ${ }^{57}$ as denúncias voltaram-se para a falta de preocupação pública com a permanência de seus antigos moradores e para a manutenção dos modos de vida a eles associados. Argumento presente em ações que, aproveitando o período das Marchas Populares, em que os moradores das freguesias disputam entre si o prêmio de melhor performance, denunciaram o risco de essa manifestação cultural deixar de existir. Como se vê na produção do documentário "Alfama é Marcha", pelo coletivo Left Hand Rotation, e no material produzido pela Junta de Freguesia de Santa Maria Maior, que, ao mesmo tempo que comemora a vitória da freguesia de Alfama, alerta que nas suas "ruas não mora já quase ninguém". De modo semelhante, viu-se nos jornais uma série de reportagens sobre estabelecimentos comerciais tradicionais e centros de lazer local que, com a redução de clientes e frequentadores moradores do bairro, corriam o risco de fechar. ${ }^{58} \mathrm{~A}$ preocupação teve ressonância na fala do presidente da República, Antônio Costa, que demonstrou em uma entrevista sua apreensão com a perda da "autenticidade" dos bairros históricos, que não seria garantida pela "conservação do patrimônio físico, mas pelas vivências dadas pelas pessoas que lá habitam".
O presidente referia-se ao risco de se transformar a cidade em "Disneylândia para adultos", 59 posição que confirma a capacidade de sensibilização e de adesão do argumento mobilizado.

\section{Os limites das ações de resistência e os riscos de desmobilização}

Para analisar a atuação de coletivos, associações e instituições envolvidos na luta pelo acesso à habitação nos bairros centrais da cidade de Lisboa, optou-se por privilegiar uma leitura que não assumisse os problemas públicos como um dado objetivo, mas como uma construção social que tem os grupos estudados como agentes coletivos responsáveis pela sua produção e sua validação social. Para isso, investigaram-se a construção de uma arena interorganizacional, a exposição dramatizada de casos de sofrimento como mecanismo de sensibilização e adesão e a produção de um repertório assentado em princípios de justiça universalizáveis, trazendo à tona elementos que podem contribuir com a reflexão sobre os modos de resistência possíveis ao processo crescente de mercantilização do espaço urbano e da moradia. Outras dimensões do problema, no entanto, acabaram ficando de fora; ausência que se buscará superar por meio de breves considerações sobre os limites e os riscos das ações de resistência investigadas.

Talvez a mais eloquente ausência seja a que diz respeito à maneira como as desigualdades sociais, étnicas e econômicas se expressam na produção do espaço urbano e nas lutas reivindicatórias desses grupos. A literatura sobre a questão habitacional em Portugal e, 
mais especificamente, em Lisboa aponta que a dificuldade de acesso à moradia digna é um problema antigo dos grupos menos privilegiados, notadamente a população mais empobrecida, imigrante, cigana e negra (Pereira et al., 2001; Castro, 2007; Carmo, Ferrão e Malheiro, 2014). 0 que parecer haver de novo nesse processo é a acelerada financeirização do mercado da habitação e do setor imobiliário em geral, colocando Lisboa na rota de investimento de uma elite capitalista transnacional (Mendes, 2017a). Como resultado, o centro e o centro histórico passam a se tornar inacessíveis também à classe média portuguesa, grupo que historicamente ocupou esses espaços. 0 que permite aventar que parte da força reivindicatória dos grupos que hoje protestam pelo direito à habitação se explica pelo lugar social ocupado por seus integrantes e pelo capital social, econômico e político por eles acumulados. Hipótese que carece de uma análise mais sistemática, mas que parece se confirmar quando se observam a composição social, econômica e étnica dos grupos com maior atuação na arena pública e os destinatários das principais ações do poder público.

Além dos limites resultantes dos recortes étnico e econômico, observa-se que, desde o final do século $X X$, novas estratégias de desmobilização vêm dificultando a construção de uma agenda coletiva de luta pelo direito à habitação. 0 que pode ser explicado por meio de um entendimento específico sobre o que é o neoliberalismo e a sua manifestação em todas as esferas da vida. Com Dardot e Laval (2016), interpreta-se que, a partir do fim da década de 1970 e início dos anos 1980, é inaugurada uma nova "razão de mundo", que altera a forma como somos levados a pensar e a nos relacionar com os outros e com nós mesmos. Trata-se, segundo os autores, de uma racionalidade que "excede em muito a esfera mercantil e financeira [...] produzindo uma subjetividade 'contábil pela criação de concorrência sistemática entre os indivíduos" (p. 30). Todo tipo de ação coletiva, nesse sentido, tem a sua condição de existência afetada, visto que os indivíduos são submetidos ao regime de competição.

Como parte dessa mudança, está a transferência da responsabilidade pela construção e pela aquisição da moradia aos agentes privados, tanto por meio de isenções fiscais voltadas para o setor imobiliário, como pela subvenção de crédito para a aquisição da casa própria. Medidas que foram acompanhadas pelo crescente desinvestimento na habitação social pública, fortalecendo o processo de deterioração e estigmatização desses espaços. 0 que estava em jogo era a inauguração do modelo de fornecimento de bem-estar por meio do acesso privado à habitação, processo que contribuiu com a erosão das condições de engajamento do trabalhador nas lutas coletivas e favoreceu o seu engajamento com a financeirização via pagamento de juros.

Nas primeiras décadas do século XXI, as políticas voltadas para a recuperação do parque habitacional nas áreas centrais e históricas foram acompanhadas pela desregulação do mercado financeiro, a flexibilização dos contratos de aluguel e o incentivo ao investimento estrangeiro. No plano micro, onde estão os proprietários e inquilinos, a casa própria transformou-se em estoque de riqueza capaz de fornecer rendimentos extras aos que se rendessem ao microcapitalismo rentista. As plataformas peer-to-peer de aluguel de curta duração - como o AirBnB - tiveram sua procura ampliada, inserindo os proprietários no 
concorrido mercado de alojamento turístico. Orientados pela lógica da competição, os proprietários e, em alguns casos, os inquilinos (por meio da sublocação) passaram a lubrificar o mecanismo do capitalismo rentista, identificando a luta pela habitação social como uma ameaça aos seus rendimentos. Trata-se de um mecanismo sofisticado, que tem sua origem no mercado financeiro global, atravessa as políticas de Estado e, por fim, penetra na subjetividade dos indivíduos.

Ao mesmo tempo que o capitalismo financeiro precisa dos recursos e agentes locais para se realizar, interessa destacar que as lutas urbanas também têm uma dimensão pluriescalar. Por um lado, o problema da habitação no centro histórico está diretamente relacionado à capacidade de agentes globais reproduzirem na escala local os interesses do grande capitalismo globalizado, engajando desde a autarquia municipal até os pequenos proprietários de imóveis. Por outro, as redes de lutas locais se conectam com redes globais de enfrentamentos, como a Left Hand Rotation e a Rede Set. Iniciativas que, apesar de serem vistas com grande entusiasmo por seus integrantes e ativistas, demandam uma investigação mais cuidadosa para se comprovar a sua capacidade e sua eficiência enquanto dispositivo de reivindicação local.

\section{[I] https://orcid.org/0000-0001-7930-0492}

Universidade Federal do Rio de Janeiro, Instituto de Pesquisa e Planejamento Urbano e Regional. Rio de Janeiro, RJ/Brasil.

heitorvianna@gmail.com

\section{Notas}

(1) Na imprensa e nas conversas cotidianas, a lei é comumente chamada de "Lei de Cristas". O nome faz referência à então ministra da Agricultura, do Mar, do Ambiente e do Ordenamento do Território, Assunção Cristas, responsável pelas negociações que levaram à sua aprovação.

(2) Desde 2012, a cidade de Lisboa está dividida em 5 zonas de gestão, designadas de Unidade de Intervenção Territorial: norte, oriental, ocidental, centro, centro histórico

(3) O termo "alojamento local" designa todos os imóveis que possuem autorização para prestar serviço de alojamento de curta duração, mediante remuneração, modalidade sobretudo voltada para a hospedagem turística.

(4) Entre os anos de 2011 e 2015, o país foi governado pela coligação formada pelo Partido Social-Democrata (PSD) e pelo Partido Popular (PP). 
(5) Como "problema público" entendem-se, tal como definiu Gusfield (1981, p. 5), os problemas que, diferentemente dos "problemas sociais", se transformam em questões de conflito e de controvérsia nas arenas de ação pública. Ou seja, são assuntos que exigem uma resposta pública dos que são acusados como responsáveis.

(6) O inserto é importante para evitar o risco de se cair no relativismo, crítica que, por vezes, a perspectiva de Gusfield, inspirada na antropologia simbólica, é alvo. Se, por um lado, as estatísticas, as análises científicas e os argumentos legais têm uma função simbólica de dar realidade aos problemas por ela apontados por meio de operações de seleção e focalização, por outro, elas têm como base problemas reais que aquela comunidade procura enfrentar (Cefaï, 2017, pp. 134-135).

(7) Entende-se arena pública como "constelação de cenas que se sobrepõem umas às outras, que abrem para bastidores de geometria variável, em que os graus de publicidade são determinados pelos enquadramentos dos atores e cujos auditórios mudam ao sabor das performances" (Cefaï, 2017, p. 136).

(8) Rolnik (2015, pp. 35-78) aponta que as décadas de 1970 e 1980 foram marcadas pelo desmonte de componentes básicos que sustentavam o Estado de Bem-Estar Social, o que se expressou na venda do estoque público de moradia, na estigmatização da habitação pública e na ampliação de crédito para a aquisição da casa própria.

(9) No ano de 2003, apenas 3,3\% do parque habitacional português era composto por alojamento público, enquanto, nos países do norte europeu, o percentual atingia ou ultrapassava $20 \%$ (Fonseca e Malheiros, 2011, p. 62).

(10) Em vigor desde 2009, atribui uma série de vantagens tributárias aos profissionais não residentes que solicitam residência fiscal no país.

(11) Implementado em 2012, permite que investidores estrangeiros não integrantes da União Europeia obtenham uma autorização de residência no país por meio de investimentos imobiliários.

(12) Em estudo publicado em 2011, Guerra já apontava que nas regiões de Lisboa e do Porto a procura pelo aluguel de imóveis era 10 vezes superior à oferta.

(13) Sem fazer referência à fonte do dado, a carta afirma que "nos últimos três/quatro anos, os preços da habitação para aluguel aumentaram entre $13 \%$ e $36 \%$ e, para aquisição, subiram até 46\%, consoante as zonas da cidade, de que resulta, estima-se, uma taxa de esforço com a habitação situada entre $40 \%$ e $60 \%$ do rendimento familiar, quando os padrões comuns aconselham uma taxa de esforço até 30\%" (Morar em Lisboa, 2017).

(14) Em sua análise sobre a construção de um problema público, Gusfield (1981, pp. 13-14)) diferencia a atribuição de responsabilidade de um problema por meio de dois conceitos: a "responsabilidade causal" e a "reponsabilidade política". O primeiro está ligado ao que factualmente explica a existência de um problema, enquanto o segundo está relacionado com a atribuição de um responsável pela resolução do problema.

(15) Só na imprensa escrita, é possível localizar notas e reportagens sobre a ação nos portais de $O$ Corvo, do Sapo 24, do Observador, do Idealista, do Público e do Diário de Notícias. 
(16) No site do Morar em Lisboa, estão documentados encontros com os presidentes das Juntas de Freguesia da Misericórdia, da Penha de França, de Santo António e de Santa Maria Maior, com representantes municipais do Bloco de Esquerda, do Partido Os Verdes, do Partido Socialista e do Partido Comunista Português e o próprio presidente da Câmara Municipal e, por fim, com o Secretário de Estado de Habitação e outros integrantes da Assembleia da República. Assim como relata a promoção do debate sobre a habitação em Lisboa com os candidatos à Câmara, que contou com a presença de filiados do CDS - Partido Popular, Pessoas Animais e Natureza, Coligação Democrática Unitária, Partido Socialista, Bloco de Esquerda e Partido Social-Democrata.

(17) As juntas de freguesias são unidades de representação político-administrativa mais próximas do cidadão, sendo seus representantes eleitos pelos moradores registrados na sua área de atuação. Por isso, os residentes são comumente referidos, pela administração das juntas, como eleitores. Diferentemente dos bairros, categoria sem força administrativa na Lisboa contemporânea, mas frequentemente mobilizada pelos moradores em referência às localidades que se distinguem pelas identidades coletivas dos grupos que deles fazem parte. .

(18) Morar em Lisboa, Associação Habita pelo Direito à Habitação e à Cidade, Movimento Quem vai poder Morar em Lisboa, Aqui Mora Gente, Associação dos Inquilinos Lisbonenses e Vizinhos do Areeiro.

(19) Artéria - Humanizing Architecture, Atelier Mob - Arquitectura Design e Urbanismo, FAZ - Fundo de Arquitectura Social, Cooperativa Trabalhar com os $99 \%$.

(20) Associação do Patrimônio e População de Alfama e Associação Portuguesa para a Reabilitação Urbana e Defesa do Patrimônio.

(21) Associação Portuguesa de Arte Fotográfica, Largo Resistências, c.e.m - centro em movimento, FrameColectivo, Pátio Ambulante, Sociedade Boa União e Plano Lisboa.

(22) Left Hand Rotation e Academia Cidadã.

(23) Geota - Grupo de Estudos de Ordenamento do Território e Ambiente e Gestual - Grupo de Estudos Socioterritoriais, Urbanos e de Ação Local da Faculdade de Arquitectura da Universidade de Lisboa.

(24) Associação de Combate à Precariedade - Precários Inflexíveis, União dos Sindicatos de Lisboa, Sindicato dos Professores da Grande Lisboa, A Voz do Operário, Inter-Reformados e Associação de Reformados, Pensionistas e Idosos dos Olivais.

(25) Bairros Associação de Desenvolvimento Local, Renovar a Mouraria e PAR - Respostas Sociais.

(26) Associação das Colectividades do Concelho de Lisboa e Lusitano Clube.

(27) Cooperativa Fruta Feia e Gaia - Grupo de Acção e Intervenção Ambiental.

(28) Grupo de Ativista em Tratamento.

(29) Transparência e Integridade.

(30) As relações de força e de dominação têm um lugar particular na tradição pragmatista, que, ao levar a sério a capacidade crítica dos atores, acaba por rejeitar uma análise da sociedade centrada nas relações de força, entre os que têm poder e os que dele não dispõem. O que, como sugerem os escritos de Boltanski $(2014,2016)$, não significa negar que os atores dispõem de capacidades desiguais nas disputas que engendram no mundo social. 
(31) Nos últimos quatro anos, a Freguesia de Santa Maria Maior registrou a saída de mais de dois mil eleitores, o que representou a perda de $16,5 \%$ de sua população. Ao mesmo tempo, foi a região com o maior número de imóveis licenciados como alojamento turístico, concentrando $28 \%$ dos registros da cidade (Quaternaire Portugal, 2017).

(32) O fato de o seu representante ser filiado do Partido Socialista, o mesmo do presidente da Câmara Municipal, Fernando Medina, também deve ser considerado no processo de negociação e sensibilização.

(33) As juntas de freguesias são responsáveis por "contribuir para as políticas municipais de habitação, através da identificação de carências habitacionais e fogos disponíveis [imóveis destinados à habitação] e, ainda, da realização de intervenções pontuais para melhoria das condições de habitabilidade" (Assembleia da República, 2012). Responsabilidade que foi respondida pela freguesia em questão por meio de estudos sobre o número de imóveis desocupados e de moradores despejados e, no plano da ação, pela criação de um grupo de apoio jurídico aos moradores e o reforço de ações sociais voltadas para a subsistência da comunidade.

(34) Boltanski (2000, p. 59) define o "trabalho de modelização" dos atores como a competência de "ter acesso para produzir, em situações determinadas, argumentos aceitáveis para os demais ou, como frequentemente se diz, convincentes, isso é, capazes de sustentar uma pretensão de inteligibilidade e dotadas também de um elevado grau de objetividade e, por conseguinte, de universalidade".

(35) “Carta que ordena despejo na Mouraria 'não tem qualquer validade'” (Público, 22/2/2018); "Para Carla, Maria e Rafael, a crise começou agora. Moradores do centro histórico de Lisboa pressionados a deixarem as suas casas” (Público, 31/3/2018); “'O meu marido nasceu e morreu nesta casa. Não é agora que vou sair'. Famílias inteiras estão revoltadas e residentes dos mesmos prédios sabem que estão a ser enganados" (Público, 31/3/2018).

(36) “Para Carla, Maria e Rafael, a crise começou agora. Moradores do centro histórico de Lisboa pressionados a deixarem as suas casas" (Público, 31/3/2018].

(37) O coletivo Stop Despejo relatou as ameaças sofridas pelas famílias do prédio Santos Lima por meio de um pequeno vídeo; a Junta de Freguesia de Santa Maria Maior divulgou os casos de violência para imprensa no evento "Rostos do Despejo"; e os coletivos Habita e Left Hand Rotation produziram um curta-metragem que, entre outras questões, abordam o assédio sofrido pelos moradores da rua dos Lagares, Mouraria.

(38) Na esfera nacional, mais de três dezenas de diplomas - termo nativo para os textos legislativos foram apresentados na Assembleia da República sobre o tema da habitação nos anos de 2017 e 2018. Entre os autores, estão: Partido Socialista, Bloco de Esquerda, Verdes, Partido Comunista Português, Partido Social-Democrata e CDS Partido Popular.

(39) "Pedidos de ajuda por despejo obrigam câmara de Lisboa a criar gabinete de apoio" (Público, 31/3/2018); "Bloco propõe limites ao aumento de rendas e multas a bullying dos senhorios" (Público, 27/4/2018); “Linha SOS Despejo de Lisboa atendeu 141 pessoas desde junho" (Público, 19/9/2018).

(40) “'O meu marido nasceu e morreu nesta casa. Não é agora que vou sair'. Famílias inteiras estão revoltadas e residentes dos mesmos prédios sabem que estão a ser enganados” (Público, 31/3/2018). 
(41) "PS apresenta diploma para condicionar despejos de maiores de 65 anos e de deficientes", (Público, 27/4/2018; "Arrendamento 'vitalício' para idosos e desconto de IRS nos contratos longos" (Público, 4/5/2018); "Esquerda aprova suspensão de despejos até nova lei das rendas" (Público, 23/5/2018).

(42) “Estado apoia pais sozinhos que percam contrato de arrendamento" (Público, 17/4/2018).

(43) A exceção se dá nas disputas no âmbito da cena parlamentar, na qual o repertório jurídico é constantemente empregado.

(44) "Fundos imobiliários, bancos e seguradoras compraram ruas inteiras e as consequências são desastrosas'” (Público, 31/3/2018); "Preços baixos, lei Cristas e segurança explicam invasão de estrangeiros" (Público, 29/5/2018).

(45) “Maioria dos novos contratos de arrendamento são de apenas um ano" (Público, 23/4/2018); "Comissão Europeia acusada de impedir esforços das cidades para limitar o Airbnb" (Público, 21/5/2018); "Preços baixos, lei Cristas e segurança explicam invasão de estrangeiros" (Público, 29/5/2018).

(46) "Crónica de um arrendamento impossível" (Público, 30/10/2016); "Número de famílias sobrecarregadas com custos da habitação quase duplicou" (Público, 21/4/2018); "Lisboa sobe 44 posições no ranking mundial das cidades mais caras" (Público, 26/6/2018); "Falta de pagamento de renda motiva 90\% dos despejos" (Público, 28/6/2018); "Rendas das casas registam 'subida mais acentuada dos últimos oito anos'” (Público, 11/7/2018); "Aumento das rendas em 2019 será o maior dos últimos seis anos" (Público, 1%/9/2018).

(47) No modelo desenvolvido por Boltanski e Thévenot (2006), a tensão entre esses dois mundos expressa-se no que eles denominaram "cité mercantil" e "cité civil": na primeira delas, reina as relações de competição por bens escassos, reduzindo os homens a compradores e vendedores; no segundo, a vontade egoística deve ser abandonada em favor do interesse geral, acentuando, portanto, as relações coletivas. Apesar de o modelo desenvolvido pelos autores ter servido de referência para pensar os princípios que integram o repertório dos atores e coletivos estudados, optou-se por não operacionalizar suas categorias. No caso empregado, o par antitético valor de uso versus valor de troca - mobilizado em abundância nos estudos urbanos marxistas - é suficiente para dar conta do jogo de valoração operado pelos grupos em análise.

(48) O artigo 65 da Constituição da República Portuguesa (Assembleia da República, 2005) diz: "Todos têm direito, para si e para a sua família, a uma habitação de dimensões adequadas, em condições de higiene e conforto e que preserve a intimidade pessoal e a privacidade familiar".

(49) “Procura-se: cidade com casas acessíveis e turismo equilibrado" (Público, 29/9/2017); "Os centros das cidades estão a ser reconstruídos ao ritmo de T0 e T1. A 'financeirização' da habitação urbana está a impor tipologias pequenas nos prédios reabilitados" (Público, 14/11/2017); "Rock in Riot - música e descontentamento contra a gentrificação de Lisboa” (Público, 23/3/2018); “'Fundos imobiliários, bancos e seguradoras compraram ruas inteiras e as consequências são desastrosas'” (Público, 31/3/2018); "Para salvar Lisboa. Costa diz claramente, como primeiro-ministro, o que toda a gente sabe" (Público, 20/5/2018); "Preços baixos, lei Cristas e segurança explicam invasão de estrangeiros" (Público, 29/5/2018); "Condenados à periferia. Paradoxalmente, as cidades repletas serão cada vez mais cidades esvaziadas” (Público, 27/7/2018); “Quantos turistas pode Lisboa receber sem prejudicar a cidade?" (Público, 28/8/2018). 
(50) Na exposição Futuros de Lisboa, promovida pelo Museu da Cidade, foi exibida uma imagem representando o hipotética entrega da Praça do Comércio, uma das principais da cidade, para um complexo hoteleiro, interditando o livre acesso da população. Imagem distópica que encontra eco nos protestos contra o fechamento do miradouro do Adamastor, sob a denúncia de que o pedido havia partido de um hotel incomodado com o barulho de seus visitantes. "O Terreiro do Paço vai ser um hotel... numa Lisboa imaginada" (Público, 3/7/2018; "Grupo de lisboetas teme 'higienização social' em Santa Catarina” (Público, 17/8/2018).

(51) Desde o momento em que foi cunhado (Glass, 1964), o conceito foi mobilizado para interpretar a lógica capitalista de produção do espaço urbano (Smith, 2012), para identificar os atores e grupos pioneiros do processo de elitização dos espaços (Featherstone, 1991), para compreender as transformações do ambiente urbano e da paisagem urbana (Zukin, 1991), para analisar os efeitos dos processos de reestruturação urbana de ordem neoliberal (Mendes, 2013) e para descrever a luta de classe que tem as antigas áreas populares como palco (Harvey, 2014). Com a intensificação das lutas urbanas e, sobretudo, com a radicalização do processo de expulsão das classes populares das áreas mais centrais das cidades, o conceito passa a ganhar uma conotação mais política, integrando o repertório daqueles grupos que lutam por uma cidade menos segregada e mais plural.

(52) "Rock in Riot - música e descontentamento contra a gentrificação de Lisboa. 'Gen-tri-ficar'”, (Público, 23/3,2018); “'Não podemos ter os centros das cidades como Disneylândias para adultos'. Numa entrevista a propósito dos 20 anos da Expo'98, António Costa mostra-se preocupado com a gentrificação de Lisboa e do Porto" (Público, 18/5/2018); “O samba sem fronteiras da gentrificação" (Público, 28/5/2018).

(53) “Dez teses sobre o centro histórico de Lisboa." (João Seixas, Público, 8/8/2016); “Entrevista com Luís Mendes: 'Mouraria, Intendente e Anjos estão a revelar-se uma nova fronteira de interesse para o capital imobiliário'” (Público, 13/10/2016); "Os centros das cidades estão a ser reconstruídos ao ritmo de T0 e T1. A 'financeirização' da habitação urbana está a impor tipologias pequenas nos prédios reabilitados" (Público, 14/11/2017); “O Capitalismo imobiliário e a crise da habitação em Lisboa" (Cocola Gant, Agustin, Le Monde Diplomatique Portugal, 1/2/2018); "Reabilitação urbana em Alfama é quase sempre 'seletiva' e 'virada para o turismo', afirma a pesquisadora Ana Gago" (O Corvo, 19/4/2018).

(54) É o caso da carta pública do Morar em Lisboa, que teve entre seus elaboradores os pesquisadores Ana Bigotte Vieira (Ifil-Nova), Joana Braga (ISCTE-UL), Antonio Brito Guterres (ISCTE-UL), Luís Mendes (Igot-UL) e João Seixas (FCSH-UNL).

(55) O coletivo Habita, por exemplo, tem entre seus integrantes professores e pesquisadores universitários, tais como: Luís Mendes (Igot-UL), André Carmo (Igot-UL), Eduardo Ascensão(Igot-UL), Ana Esteves (Igot-UL), Caterina Francesca di Giovanni (ISCTE-Nova), Ana Gago (Igot-UL), Agustin Cocola-Gant (CEG-UL) e Jorge Malheiros (CEG-UL). 
(56) É exemplar, nesse sentido, a atuação do pesquisador Luís Mendes, cujo artigo "Manifesto Anti-Gentrificação" (Mendes, 2017b) acabou servindo de base para se discutirem, na Câmara Municipal, medidas para frear o processo de aburguesamento dos bairros históricos e diminuir o impacto negativo da atividade turística nesses bairros. O que mais tarde resultou no convite do Partido Comunista Português para a realização de um estudo sobre a capacidade de carga turística da cidade no ano de 2018; documento que hoje, entre outros, orienta as propostas de ordenamento e regulação da atividade turística na Câmara. Como foi anunciado na seguinte reportagem: "Quantos turistas pode Lisboa receber sem prejudicar a cidade? PCP defende o estudo e definição da 'capacidade de carga turística' da cidade e, ao mesmo tempo, um plano de ordenamento para a atividade” (Público, 28/8/2018).

(57) Ações que tiveram como marco o decreto-lei n. 104, de 7 de maio de 2004, que criou o Regime Jurídico Excepcional de Reabilitação Urbana de Zonas Históricas e de áreas Críticas de Recuperação Urbanísticas.

(58) "Os artesãos (ainda) estão no centro histórico" (Público, 20/11/2017; "Ginásio do Alto do Pina está em risco de ficar sem a sede que ocupa há 106 anos" (Público, 23/11/2017); "Livros e antiguidades estão a ser expulsos da rua do Alecrim" (Público, 21/3/2018); "Após o fecho da Casa Frazão, pede-se um limite para as rendas dos espaços históricos” (Público, 16/4/2018).

(59) “'Não podemos ter os centros das cidades como Disneylândias para adultos'. Numa entrevista a propósito dos 20 anos da Expo'98, António Costa mostra-se preocupado com a gentrificação de Lisboa e do Porto" (Público, 18/5/2018).

\section{Referências}

AMILCAR, A.; CARREIRAS, M.; MALHEIROS, J.; FERREIRA, B. (2011). Notas sobre política de habitação em Portugal - trajectórias e possibilidades. In: VIII CONGRESSO DA GEOGRAFIA PORTUGUESA. Anais... Lisboa.

ASSEMBLEIA DA REPÚBLICA (2005). Constituição da República Portuguesa, 7ạ revisão aprovada pela lei $\mathrm{n} .1 / 2005$ de 12 de agosto.

(2012). Reorganização administrativa de Lisboa, aprovada pela lei n. 56/2012 de 8 de novembro.

BARATA, A. (2014). “Conceber o estado social”. In: CARMO, R. M.; BARATA, A. (orgs.). Estado social. De todos para todos. Lisboa, Tinta da China.

BIDOU-ZACHARIASEN, C. ([2003] 2006). De volta à cidade. Dos processos de gentrificação às políticas de 'revitalização' dos centros urbanos. São Paulo, Annablume.

BOLTANSKI, L. (2000). El amor y la justicia como competências. Tres ensayos de sociologia de la accion. Buenos Aires, Amorrortu Editores.

(2014). De la crítica. Compendio de sociología de la emancipación. Madri, Ediciones Akal.

(2016). "Sociologia crítica ou sociologia da crítica". In: VANDENBERGUE, F.; VÉRAN, J. (orgs.). Além do habitus: teoria social pós-bourdieusiana. Rio de Janeiro, 7 Letras. 
BOLTANSKI, L.; THÉVENOT, L. (2006). On justification. Economies of worth. Princeton, Princeton University Press.

CARMO, A.; FERRÃO, J.; MALHEIROS, J. (2014). “Geografias do Estado Social: reorganização territorial, habitação e urbanismo". In: CARMO, R.; BARATA, A. (orgs.). Estado social. De todos para todos. Lisboa, Tinta da China.

CASTRO, A. (2007). Dos contextos locais à invisibilidade política: discussão em torno dos ciclos de exclusão habitacional dos ciganos em Portugal. Cidades, comunidades e territórios - ISCTE. Lisboa, n. 15, pp. 63-86.

CEFAÏ, D. (2002). "Qu'est-ce qu'une arène publique? Quelques pistes pour une approche pragmatiste". In: CEFAII, D.; JOSEPH, I. (coords.). L'heritage du pragmatisme. Conflits d'urbanité et épreuves de civisme. La Tour d'Aigues, Éditions de l'Aube.

CEFAÏ, D. (2009). "Como nos mobilizamos? A contribuição de uma abordagem pragmatista para a sociologia da ação coletiva". Dilemas - Revista de Estudos de Conflito e Controle Social [online], v. 2 , n. 4, pp. 11-48.

(2011). “Como uma associação nasce para o público. Vínculos lociais e arena pública em torno da Associação La Bellevilleuse, em Paris”. In : CEFAï, D.; MELLO, M. A.; MOTA, F. R.; VEIGA, F. B. (orgs.). Arenas públicas. Por uma etnografia da vida associativa. Niterói, Editora da UFF.

(2017). Públicos, problemas públicos, arenas públicas... O que nos ensina o pragmatismo (Parte 2). Novos estudos - Cebrap [online], v. 36, n. 2, pp. 129-142.

CEFAÏ, D.; MOTA, F. R.; VEIGA, F. B. (2011). “Introdução. Arenas públicas. Por uma etnografia da vida associativa”. In : CEFAÏ, D.; MELLO, M. A.; MOTA, F. R.; VEIGA, F. B. (orgs.). Arenas públicas. Por uma etnografia da vida associativa. Niterói, Editora da UFF.

CONFIDENCIAL IMOBILIÁRIO (2018). Portuguese housing market survey, junho. Disponível em: https:// confidencialimobiliario.com/editorial/portuguese-housing-market-survey/. Acesso em: 13 ago 2020.

DARDOT, P.; LAVAL, C. (2016). A nova razão do mundo: ensaio para a sociedade neoliberal. São Paulo, Boitempo.

FEATHERSTONE, M. (1991). Consumer Culture and Postmodernism. Londres, Sage.

FONSECA, L.; MALHEIROS, J. (coords.) (2011). Acesso à habitação e problemas residenciais dos imigrantes em Portugal. Lisboa, Observatório da Imigração.

GLASS, R. (1964). Introduction to London: aspects of change. Londres, MacGibbon and Kee.

GUERRA, I. (2011). As políticas de habitação em Portugal: à procura de novos caminhos. Cidades, comunidades e territórios - ISCTE. Lisboa, n. 22, pp. 1-42.

GUSFIELD, J. (1981). The culture of public problems: drinking-driving and the symbolic order. Chicago, University of Chicago Press.

(2012). "Significations disputées. Contester la propriété et l'autorité des problèmes sociaux". In: CEFAI, D.; TERZI, C. (coords.). L'expérience des problèmes publics. Paris, École des Hautes Études em Sciences Sociales. 
HARVEY, D. (2012). Condição pós-moderna. Uma pesquisa sobre as origens da mudança cultural. São Paulo, Loyola.

(2014). Cidades rebeldes, do direito à cidade à revolução urbana. São Paulo, Martins Fontes.

INSTITUTO NACIONAL DE ESTATÍSTICA DE PORTUGAL (2011). Censo de 2011 - XV Recenseamento geral da população e V Recenseamento geral da habitação. Disponível em: https://www.ine.pt/ xportal/xmain?xpid=INE\&xpgid=ine_publicacoes\&PUBLICACOESpub_boui=156651739\&PUBLIC ACOEStema=55466\&PUBLICACOESmodo=2. Acesso em: 13 ago 2020.

(2013). Retrato territorial de Portugal: Sistema urbano, transformações familiares, reabilitação e arrendamento Habitacionais: Uma perspectiva territorial - 2011. Disponível em: https://www.ine.pt/xportal/xmain?xpid=INE\&xpgid=ine_destaques\&DESTAQUESdest_ boui=160953661\&DESTAQUESmodo=2. Acesso em: 13 ago 2020.

MENDES, L. (2013). A regeneração urbana na política de cidades: Inflexão entre o fordismo e o pósfordismo. Urbe - Revista Brasileira de Gestão Urbana [online], v. 5, n. 1, pp. 33-45.

MENDES, L. (2014). Gentrificação e políticas de reabilitação urbana em Portugal: uma análise crítica à luz da tese da rent gap de Neil Smith. Cadernos Metrópole [online], v. 16, n. 32, pp. 487-511.

MENDES, L. (2017a). Gentrificação turística em Lisboa: neoliberalismo, financeirização e urbanismo austeritário em tempos de pós-crise capitalista 2008-2009. Cadernos Metrópole. São Paulo, v. 19, n. 39, pp. 479-512.

(2017b). Manifesto anti-gentrificação. Revista do Niep - Marx e o Marxismo [online], v. 5, n. 9, pp. 322-337

MORAR EM LISBOA (2017). Carta aberta ao governo, aos deputados, ao município, aos cidadãos! Disponível em: http://moraremlisboa.org/. Acesso em: 13 ago 2020.

MOURA, H. V. (2018). Entrevista com Luís F. G. Mendes - Gentrificação e turistificação em Lisboa. Da financeirização das políticas urbanas à luta urbana. e-metropolis [online], n. 35, ano 9, pp. 65-72.

NUNES, J. P. S. (2010). Dos subúrbios citadinos aos subúrbios metropolitanos. Estrutura de povoamento e morfogénese da metrópole de Lisboa (1950-2001). Cidades - Comunidades e Território [online], n. 20/21, pp. 123-137.

PEREIRA, A.; SOUSA, D.; BAPTISTA, I.; PERISTA, P. (2001). Habitat e minorias. Processo de (des) integração de grupos étnicos em Lisboa e Porto. Cidades, comunidades e territórios - ISCTE. Lisboa, n. 3, pp. 93-109.

QUATERNAIRE PORTUGAL (2017). Estudo sobre as dinâmicas residenciais, econômicas e urbanísticas no centro histórico de Lisboa. Disponível em: http://www.quaternaire.pt/Destaques/NovasDinamicas-Residenciais-Economicas-e-Urbanisticas-no-Centro-Historico-de-Lisboa. Acesso em: 13 ago 2020.

ROLNIK, R. (2015). Guerra dos lugares: a colonização da terra e da moradia na era das finanças. São Paulo, Boitempo.

SALGUEIRO, T. B. (2001). Lisboa, periferia e centralidades. Lisboa, Celta.

SANTOS, A. C.; TELES, N.; SERRA, N. (2014). Finança e habitação em Portugal. Cadernos do Observatório - Centro de Estudos Sociais. Coimbra, pp. 1-59. 
SERRA, N. (1997). Território e habitação em Portugal. Oficina do CES - Centro de Estudos Sociais. Coimbra, n. 101, pp. 1-17.

SILVA, C. N. (1994). Política urbana em Lisboa-1926-1974. Lisboa, Livros Horizonte.

SMITH, N. (2012). La nueva frontera urbana. Ciudade revanchista y gentrificatión. Madrid, Traficante de Sueños.

SPECTOR, M.; KITSUSE, J. I. (2001). Constructing social problems. Washington, Library of Congress. (2012). "Sociologie des problèmes sociaux. Un modele d'historie naturelle". In: CEFAI, D.; TERZI, C. (coords.). L'expérience des problèmes publics. Paris, École des Hautes Études em Sciences Sociales.

ZUKIN, S. (1991). Landscapes of power. From Detroit to Disney World. Califórnia, University of California Press.

Texto recebido em 28/fev/2019

Texto aprovado em 15/maio/2020 